\title{
Volunteering Attitude, Mental Well-Being, and Loyalty for the Non-Profit Religious Organization of Volunteer Tourism
}

\author{
Heesup Han ${ }^{1}\left(\mathbb{D}\right.$, Antonio Ariza-Montes ${ }^{2} \mathbb{D}$, Pilar Tirado-Valencia ${ }^{3} \mathbb{C}$ and Soyeun Lee ${ }^{1, *(\mathbb{C}}$ \\ 1 College of Hospitality and Tourism Management, Sejong University, 98 Gunja-Dong, Gwanjin-Gu, \\ Seoul 143-747, Korea; heesup.han@gmail.com \\ 2 Department of Management, Universidad Loyola Andalucía, C/Escritor Castilla Aguayo, 414004 Córdoba, \\ Spain; ariza@uloyola.es \\ 3 Financial Economics and Accounting Department, Universidad Loyola Andalucía, C/Escritor Castilla \\ Aguayo, 414004 Córdoba, Spain; ptirado@uloyola.es \\ * Correspondence: 1sy2you82@hotmail.com
}

Received: 16 April 2020; Accepted: 2 June 2020; Published: 5 June 2020

\begin{abstract}
The present research aimed to explore volunteer travelers' loyalty formation for the non-profit religious organization of volunteer tourism by considering the gender influence. A quantitative process along with a survey method was utilized to attain the research purpose. Our empirical results showed that awareness of the need, performance of the organization, attitude, and the mental well-being were critical contributors to increasing loyalty. Attitude and mental well-being were vital mediators. The performance of the non-profit religious organization included a comparative importance in building loyalty. In addition, gender moderated the effect of awareness of the need and performance of the organization on the travelers' attitudes toward it. As very little is known about volunteer tourists' behaviors, the current study satisfactorily provides an apparent comprehension regarding how their loyalty for the non-profit religious organization is generated and what factors drive this loyalty.
\end{abstract}

Keywords: non-profit religious organization; volunteers; mental well-being; gender; attitude; loyalty

\section{Introduction}

Fostering individuals' altruistic travel behaviors is an essential facet of moving toward a responsible tourism future across the world [1-3]. Undoubtedly, volunteer tourism activities are altruistic behaviors that are considered as a critical form of this type of responsible tourism [4-6]. According to Brown [7], international volunteer tourism can be dated back to around 1915. Although a debate/critique exists, tourism scholars generally agree that the concept of volunteer tourism comprises of the basic meaning of helping communities in certain contexts, which include helping disaster victims or relief, improving the well-being of local communities, protecting the environment, habitat, or endangered species, and distributing necessities and resources [2-4,7]. Volunteer tourism is certainly an emerging tourism phenomenon, which is drawing increasing attention from international travelers $[5,8]$.

Concurrently, diverse volunteer tourism organizations nowadays play a key role in this fast-growing tourism sector [1,2]. Particularly, non-profit religious organizations are major players in boosting the growth of volunteer tourism [5]. Nonetheless, due to the abundant number of these types of organizations and the reduced capacity of them in the tourism marketplace, the key issue among non-profit religious volunteer tourism organizations is the long-term survival [1]. Building loyalty that contributes to maintaining the existing volunteers and attracting/recruiting new volunteer travelers is therefore becoming the fundamental requisite of the success of the non-profit religious volunteer tourism organizations. 
Many studies indicated the criticality of awareness of the need, performance, attitude, mental well-being, and gender in generating traveler loyalty [9-15]. Lind et al. [13] found that travelers' awareness of the need strengthens their pro-social decision for traveling mode choice behaviors. Oliver [14] and Taylor and Baker [15] insisted that customer perception regarding the performance of the corporation/brand is a vital contributor to inducing his/her pleasurable experiences and loyalty behaviors. In addition, Meng et al. [5] asserted that individuals' attitude toward altruistic tourism activities results in the increased loyalty intention for these types of behaviors. Hwang and Lee [11] found that tourists' mental well-being is a crucial driver of their positive post-purchase behavior for tourism products. Despite the importance of these variables stressed in the extant tourism studies, little research has uncovered the convoluted interrelationships among them. In addition, previous studies examined the motives, types, concepts, description of the tourist experience, which are limited aspects. More research needs to be conducted to understand volunteer traveler behavior including what factors drive them to engage in volunteer tourism and how their loyalty to a particular organization is generated. Moreover, there are limited prior studies that research loyalty generation processes in tourists participating in non-profit religious organizations. In that sense, the current study contributes to the body of volunteer tourism literature with substantive findings. Moreover, the existing studies in various tourism/hospitality sectors often stressed the importance of the gender difference in traveler behaviors $[9,16,17]$. These researchers consider that gender contains a moderating nature, but its moderating role in the process of building volunteer travelers' loyalty has been rarely unearthed. The extant theoretical frameworks in the previous studies pertinent to volunteer travelers' behavior therefore need to be deepened through the integration of the gender effect. In this regard, the present research satisfactorily demonstrated evidence of a gender moderation effect. Our finding can provide both theoretically and managerially important implication to practitioners of non-profit religious organization when inducing volunteer's favorable attitude, which in turn generates loyalty.

Overall, the framework, which includes the awareness of the need, performance, attitude, mental well-being, and gender, has been scarcely applied to comprehend the volunteer traveler decision-making process for the non-profit religious volunteer tourism organization. The influence of these variables and gender (crucial moderator) on volunteer travelers' loyalty generation processes undoubtedly needs more attention.

Accordingly, the present study was an empirical endeavor to explore a conceptual framework that elucidates the establishment of volunteer traveler loyalty for the non-profit religious organization of volunteer tourism by taking the influence of gender into account. Specifically, the current research is intended to (1) uncover the role of awareness of the need, performance of the organization, attitude toward the organization, and mental well-being in increasing loyalty, (2) discover the mediating effect of attitude toward the organization and mental well-being, (3) explore the relative significance of study variables in affecting loyalty, and (4) explore the moderating effect of gender on the projected theoretical framework.

The outcomes of this study can help volunteer practitioners of non-profit religious organizations not only to develop useful tactics to retain existing volunteers, but also to recruit new volunteer tourists via marketing strategies. Theoretically, our findings also contribute to the volunteer tourism literature by providing important information to better explicate volunteer tourists' decisions/behaviors. The subsequent parts of this research include the literature review, methodology, and the results. Afterward, the discussion and the implications are presented.

\section{Literature Review}

\subsection{Volunteer Tourism}

Voluntourism is a recent term that combines 'volunteering' and 'tourism', which in short means volunteer activities. Similarly, voluntourism organizations define it as a combination of volunteering at the destination with typical travel elements. It refers to a form of tourism in which tourism, 
cross-cultural exchange and economic consumption are simultaneously performed while staying in other regions, away from the daily life [18]. There have been many previous studies that proposed a definition and concept of volunteer tourism in various aspects. Wearing [19] defined volunteer tourism as taking vacations to help people with material poverty or to participate in natural environment, cultural heritage maintenance, and restoration work. McGehee and Santos [20] defined paying time and money while traveling outside of one's daily activities to help communities or people in need. Common characteristics can be seen in the definition and concepts of volunteer tourism suggested in aforementioned previous studies. Volunteer tourism originates from altruistic motives of travelers such as environmental conservation and poverty alleviation $[18,21]$. Such motivation is a combination of unpaid voluntary activities and tourism elements such as vacation, and most of them are served by specialized organizations (including NGO organizations) or groups [22].

\subsection{Non-Profit Religious Organization}

A number of prior studies have explored volunteer tourism performed by non-specified groups [7, 23-26]. A great deal of previous studies discussed limited aspects such as their profiles, motivation factors, and performed experiences [27,28]. For example, Lo and Lee [27] examined the motivational factors, and identified the five key motives by conducting in-depth interviews with the volunteer tourists: cultural experience with local communities, desire to give away, shared experience with family, religious involvement, and escape from daily hustle. Unsurprisingly, "religious involvement" was one of the motives for volunteer travel, as all participants in the focus group were Christians. They stated that they wanted to help poor communities, and they also preached and hoped that the locals would "accept God's grace" [27]. However, the central motives of volunteer tourists from the previous studies identified include altruism [23,25], egoistic [23,26], and social and psychological demands [25], which are different from motives of members' participating in a religious group. Likewise, the motivation for volunteer tourism can vary depending on who the participants are and who is the host, such as non-governmental organizations, schools and religious groups. Yet, little has been discussed regarding what factors drive religious tourists to engage in and generate loyalty. In that sense, the current study contributes to the body of volunteer tourism literature with substantive findings.

\subsection{Awareness of the Need for Aid}

Schewartz [29] defined awareness of need as any type of actual or potential deficit of required, wanted, or generally owned resources that are desired by an individual, group, or a social class. Steg and De Groot [30] asserted that awareness of need is composed of a similar basis of norm-activation theory that influences human prosocial intention or behavior. For our purposes, we define awareness of need for aid as the extent to which volunteer tourism is believed to have a positive impact on the receiving community.

Campbell [31] cited the growth of various volunteer organizations and programs as strong evidence that aid demand has also increased significantly. Accordingly, for the past few decades, travelers' awareness/concern of the seriousness of social, environmental, economic, and ecological problems of local destination communities has considerably increased [1,9,32,33]. It plays a vital role in travelers' product/service/brand choices in the tourism industry $[2,7,34,35]$ as well as in travelers' altruistic intention $[9,13,36]$. Furthermore, travelers' awareness level related to the need for help plays as a crucial activator of personal moral obligations in their pro-social decision-making process $[5,13]$. For instance, Lind et al. [13] showed that high level of awareness of environmental issues leads to sustainable behavior using ecologically friendly travel mode in city. In the volunteer tourism segment, awareness of the need indicates the travelers' conscious level of the local communities' and the local people's need for help [5]. As a cognitive concept, this type of awareness of need is often considered as a critical driver of the travelers' favorable attitude and as a crucial constituent to explain the altruistic decision/loyalty formation $[1,32,35]$. 
Hypothesis 1. Awareness of the need contains a positive influence on attitude toward the non-profit religious organization.

Hypothesis 2. Awareness of the need contains a positive influence on loyalty for the non-profit religious organization.

\subsection{Performance of the Non-Profit Religious Organization}

Performance is regarded as an assessment process of the excellence or mediocrity of a particular corporation/brand and its attributes against other rival corporations/brands [15,37]. The term performance is often alternatively utilized with quality in the consumer behavior literature [14]. In the same manner, performance indicates the volunteers' evaluation process about the quality of the non-profit religious volunteer tourism organization and its program in the present research. The volunteer tourism organization provide travelers experiences of self-fulfillment, changes in values, personal enhancements, and escapism/pleasure [2,7,8]. Accordingly, when volunteers have a positive evaluation of these types of experiences, they perceive a high performance of the organization and its program. The travelers' perceived level of performance of the organization serves a crucial role for the organization to achieve its goals and provide them with satisfactory experiences $[14,38]$.

Recent studies indicated that travelers' perception regarding the performance of the organization considerably affects their decision-making process [37-39]. In particular, Kang et al. [39] found that performance and its attributes significantly influence travelers' attitudes and values in the mega-event context. More recently, Al-Ansi and Han [37] demonstrated that excellent destination performance induces Muslim travelers' high value perception, favorable attitude toward the destination, and loyalty for it in the halal tourism sector. Their result was consistent with Song et al.'s [38] earlier research, which demonstrated the significant role of festival performance in engendering travelers' fulfillment, positive attitude, and support intention. In reference to such empirical evidence, we propose that performance of the non-profit religious organization significantly affects attitude toward it and loyalty for the organization among volunteer travelers in the present research.

Hypothesis 3. Performance of the non-profit religious organization contains a positive influence on attitude toward the non-profit religious organization.

Hypothesis 4. Performance of the non-profit religious organization contains a positive influence on loyalty for the non-profit religious organization.

\subsection{Attitude toward the Non-Profit Religious Organization}

Individuals' attitude is undoubtedly a core process in eliciting travelers' positive behaviors and loyalty for the organization [10,17]. Attitude is one's general tendency toward a specific entity [40]. The entity can be an organization, a product, a service, a company, or a brand [17]. The term attitude is frequently included in social-psychological theories, since it has a substantial impact on individuals' decision formation for this type of entity [10,41]. The existing empirical studies supported the associations among traveler attitude toward the corporation/brand, mental well-being, and loyalty [41-44]. Stark et al. [44] examined children's traveler behaviors and demonstrated the associations among mental/psychological well-being, travel-related attitude, and preference. Rodríguez-Arauz et al. [43] investigated food attitudes and well-being and found the important relationship between these two variables. Their finding also revealed that the relationship is under the effect of culture. In the tourism sector, Moon et al. [42] discovered that travelers' favorable attitude toward an airport is formed based on the good quality of the airports physical surroundings, which help them feel relaxed, calm, and pleased. Their empirical outcome also indicated that these positive 
mental health outcomes result in travelers' fulfilled experiences with the airport use and loyalty for the airport. In accordance with these studies, the subsequent hypotheses were developed.

Hypothesis 5. Attitude toward the non-profit religious organization contains a positive influence on mental well-being.

Hypothesis 6. Attitude toward the non-profit religious organization contains a positive influence on loyalty for the non-profit religious organization.

\subsection{Mental Well-Being}

Well-being means travelers' appraisal of the extent that a tourism product attributes to their life quality improvement [45]. Consistently, mental well-being indicates the travelers' evaluation of the extent that a specific product boosts their life quality in a mental aspect, which includes mental/psychological health, during their product consumption. According to Hwang and Hyun [46], travelers can be calm/comfortable, pleased, and refreshed when they experience positive mental well-being. The elevations of mental well-being often enhance the central outcomes of a firm/organization, which include consumer loyalty, retention rate, and the overall image [47,48]. Specifically, in individuals' loyalty generation process or retention process, mental well-being is regarded as the core variable [45,48-50]. In the retail service sector, Troebs et al. [48] found that customer well-being is a significant contributor to elevating loyalty intentions and increasing gratitude and reciprocity. In the business context, Nadinloyi et al. [50] uncovered that employees' mental health is significantly associated with job satisfaction. Their findings also revealed that the unhealthy conditions of employees' mental health, which include feelings of stress, frustration, and burnout, have a negative influence on affective dispositions and on the company itself, which cause turnovers, absenteeism, and complaints. Kim et al. [45] explored the role of travelers' mental well-being and the empirical results showed that mental well-being is a crucial determinant of travelers' positive post-purchase decisions for a corporation. Based on this evidence, volunteer travelers' mental well-being is expected to lead toward loyalty enhancement for an organization.

Hypothesis 7. Mental well-being contains a positive influence on loyalty for the non-profit religious organization.

\subsection{Influence of Gender}

The effect of gender on most of the studies in social behavior is ground in social role theory and evolutionary psychology. According to social role theory, men and women are socialized in dissimilar ways and perform different roles in society under the assumption that people are passively given their role [51,52]. Similarly, evolutionary psychology explains the sex differences but in terms of biological adaptation. It investigated the differences between men and women by examining the various reproductive problems and linking them with psychological and behavioral characteristics [52]. Evolutionary psychology indicates that gender disparity performs a critical role in sustaining dispositions, characteristics, and patterns of social behavior [51,52].

Despite the importance of gender in social behavior, there are controversial arguments in regard to moderating role of gender. For example, Eagly and Crowley [53] performed a meta-analysis on gender disparity in helping behavior and altruism. Although their meta-analysis is based on social role theory, they concluded that it is not necessary to observe an overall effect size on gender difference in helping behavior. On the other hand, Alexander [54] observed the effect of gender on the influence of a volunteer tourism experience using a quasi-experimental study. She found certain differences in trait scores at the start due to genetic and environmental factors, and it is noteworthy to be aware of a fundamental difference. Likewise, there have been contradicting results among prior studies in moderating role of gender difference in altruistic behavior, and our study tries to fill this void. 
In recent decades, scholars in various fields have studied many interesting research topics pertinent to the impact of demographic characteristics on patrons' decision-making and consumption practice [9,55-57]. Specifically, the essential role of gender in tourists' intention is frequently emphasized by the extant studies in tourism industry $[16,55,58]$. These researchers agree that gender is one of the most fundamental socio-demographic variables affecting tourists' diverse post-purchase decision formation/behavior.

The existing tourism studies indicated that tourists' cognitive, attitudinal, and affective processes associated with their consumption decision are under the influence of gender $[16,55,56,58]$. For example, Wang et al. [58] identified that the relationships among affective and cognitive images, its antecedents, and its outcome variable are moderated by gender. Hwang and Kim [16] discovered that gender as a socio-demographic factor played an important moderating part in inducing the loyalty generation process for hospitality products. Similarly, Han et al. [55] demonstrated that gender exerted a substantial moderating effect over loyalty formation in the bicycle tourism sector. In addition, Hwang et al. [56] also identified that the cognitive and attitude association and the influence of such a relationship on intention are significantly affected by gender. The aforementioned studies demonstrated the significant moderating characteristics of gender in explicating tourists' behaviors and uncovered the disparity across male and female tourists' behaviors. Gender is irrefutably an essential socio-demographic concept in tourism industry [58]. Hence, comprehending the gender difference on tourists' consumption behavior is regarded as a critical requisite of inventing successful customer retention and loyalty enhancement strategies for every tourism organization or company [9]. Based on this, the following hypotheses are suggested.

Hypothesis 8. $(a-g)$ Gender has a significant moderating influence on the associations among awareness of the need, performance of the non-profit religious organization, attitude, mental well-being, and loyalty intention.

\subsection{Research Framework}

The Figure 1 exhibits our projected model, which contains the five variables that explicate the development of the loyalty for the non-profit religious organization among volunteer travelers. The awareness of the need, the performance of the non-profit religious organization, attitude, and the mental well-being were used as the predictors of loyalty intention. In addition, gender was employed as the moderator.

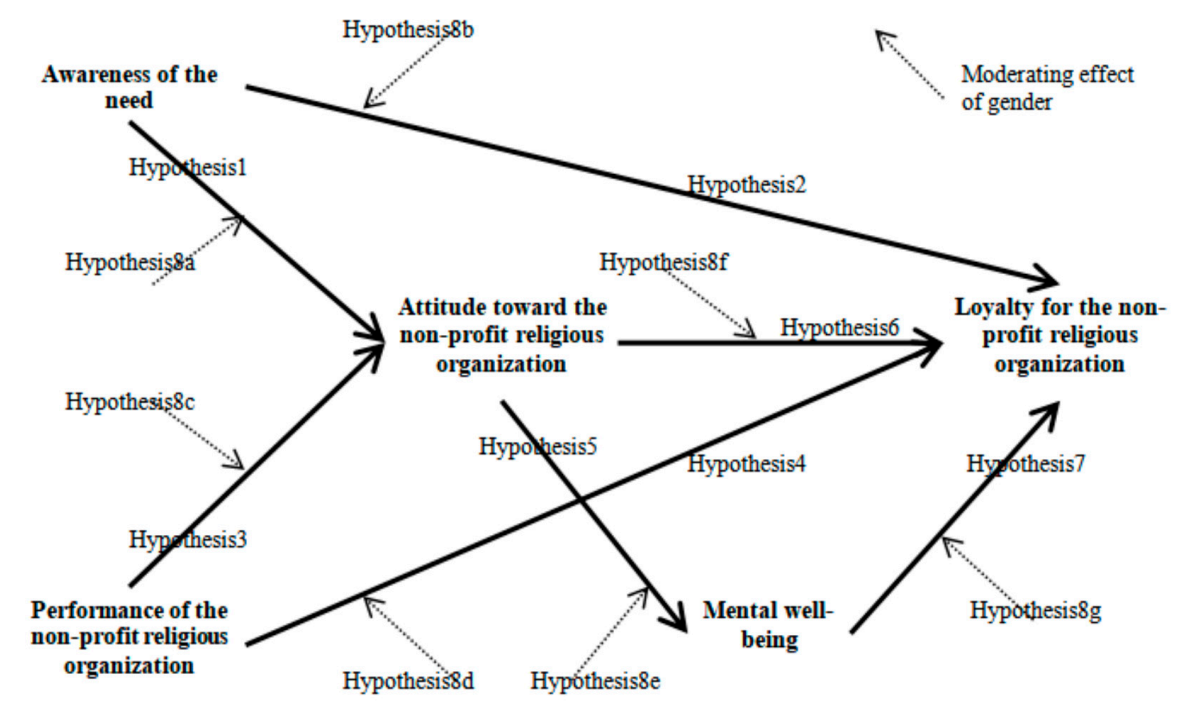

Figure 1. Proposed conceptual model. 


\section{Methods}

\subsection{Measures}

We adopted the measurement tools from the extant research for our study $[1,15,17,30,33]$. Study constructs were utilized by a seven-point Likert scale ( 1 = "strongly disagree" and 7 = "strongly agree"). Specifically, we employed 4 items to evaluate the awareness of the need, which included through the volunteer tourism program of the Good News Corps, 'I have become aware that people need help'. To measure the performance of the non-profit religious organization, we used 3 items, which included 'the Good News Corps has fulfilled all its promises'. For the assessment of attitude toward the non-profit religious organization, a total of 4 items were utilized, which included 'my evaluation of the Good News Corps' voluntary activities is positive'. In addition, we used 3 items to measure mental well-being, which included that 'the conditions of my life have become excellent after taking part in the volunteer tourism (VT) program of the Good News Corps'. Lastly, we used 2 items to assess loyalty for the non-profit religious organization, which included 'I am passionate about volunteer activities through the VT program of the Good News Corps'. The measures along with study description were contained in our survey questionnaire. The questionnaire was improved based on graduate students' feedback, who accompanied a pretest. Then it was fixed by a comprehensive review of volunteer tourism experts. A series of measurement items is presented in the Appendix A. All measurement items were evaluated using a seven-point scale ranging from strongly disagree (1) to strongly agree (7).

\subsection{Data Collection and Samples}

Survey data were collected at the volunteer tourism festival held by the Good News Corporations. Travelers who completed a year-long volunteer tourism program with the Good News Corporations along with their families were the attendees of the festival. Religious involvement can be a critical motive for volunteer tourism [27]. The program of the Good News Corporation is known as one of the biggest non-profit global volunteer tourism programs worldwide. The festival held by the corporation offers a good opportunity to interact with international volunteer tourists as the major aim of the festival is celebrating the successful completion of their long-term volunteer services. The questionnaires were distributed to the volunteer travelers in the middle of the festival. The surveyors explained the details about our research and the objectives, and then requested the travelers' participation in the survey. The respondents answered the queries in the survey questionnaire onsite. After ensuring survey completeness, the surveyors provided a little present to the respondents as a show of gratitude. Through this data collection procedure, we gained 320 usable responses, which were utilized for the data analysis.

Of the 320 respondents, $44.1 \%$ were male volunteer tourists and $55.9 \%$ were female volunteer tourists. The average age of the participants was 23.81 years. The respondents' education position was asked, and about $79.7 \%$ of the participants reported they hold a university degree (or while in school), followed by 2-year/some college degree holders (or currently enrolled in a 2-year/some college) $(13.4 \%)$, high school graduates (3.8\%), and master's degree holders (or while in school) (3.1\%). Regarding the volunteer tourism frequency, about $82.2 \%$ of the respondents reported one time, followed by 2 times $(7.8 \%), 4$ times $(6.3 \%)$, and 3 times $(3.8 \%)$. In terms of the participants' income, about $30.7 \%$ indicated an income between USD 25,000 and USD 39,999, followed by under USD 25,000 (30.4\%), between USD 40,000 and USD 54,999 (20.7\%), between USD 55,000 and USD 69,999 (8.8\%), between USD 70,000 and USD 84,999 (5.0\%), between USD 85,000 and USD 99,999 (2.2\%), and USD 100,000 or higher (2.2\%).

\section{Results}

\subsection{Confirmatory Factor Analysis}

In order to validate internal and external consistency of our research construct we conduct a confirmatory factor analysis (CFA) using AMOS 20. The result showed our model included adequate fit 
indices. The result of the composite reliability (CR) assessment indicated sufficient internal consistency and reliability of constructs, as all factor loadings were close or above the cutoff of 0.700 [59] (see Table 1); awareness of the need $=0.878$, performance of the non-profit religious organization $=0.859$, attitude toward the non-profit religious organization $=0.937$, mental well-being $=0.967$, and loyalty for the non-profit religious organizations $=0.693$. In addition, the average variance extracted (AVE) exceeded the minimum cut-off of 0.500 [59]; awareness of the need $=0.644$, performance of the non-profit religious organization $=0.672$, attitude toward the non-profit religious organization $=0.787$, mental well-being $=$ 0.527 , and loyalty for the non-profit religious organizations $=0.531$, indicating the convergent validity. Moreover, all AVEs were greater than the squared correlations between the two constructs, which supports discriminant validity.

Table 1. Measurement model assessment results.

\begin{tabular}{|c|c|c|c|c|c|c|c|c|}
\hline Variables & (a) & (b) & (c) & (d) & (e) & $\begin{array}{l}\text { Mean } \\
\text { (SD) }\end{array}$ & CR & AVE \\
\hline $\begin{array}{c}\text { (a) Awareness of the } \\
\text { need }\end{array}$ & 1.000 & - & - & - & - & $\begin{array}{c}6.344 \\
(0.746)\end{array}$ & 0.878 & 0.644 \\
\hline $\begin{array}{l}\text { (b) Performance of the } \\
\text { non-profit religious } \\
\text { organization }\end{array}$ & $\begin{array}{c}0.557^{\mathrm{a}} \\
(0.310)^{\mathrm{b}}\end{array}$ & 1.000 & - & - & - & $\begin{array}{c}6.446 \\
(0.779)\end{array}$ & 0.859 & 0.672 \\
\hline $\begin{array}{l}\text { (c) Attitude toward } \\
\text { the non-profit } \\
\text { religious organization }\end{array}$ & $\begin{array}{c}0.647 \\
(0.419)\end{array}$ & $\begin{array}{c}0.709 \\
(0.503)\end{array}$ & 1.000 & - & - & $\begin{array}{c}6.512 \\
(0.719)\end{array}$ & 0.937 & 0.787 \\
\hline (d) Mental well-being & $\begin{array}{c}0.622 \\
(0.387)\end{array}$ & $\begin{array}{c}0.549 \\
(0.301)\end{array}$ & $\begin{array}{c}0.640 \\
(0.410)\end{array}$ & 1.000 & - & $\begin{array}{c}6.130 \\
(0.895)\end{array}$ & 0.967 & 0.527 \\
\hline $\begin{array}{l}\text { (e) Loyalty for the } \\
\text { non-profit religious } \\
\text { organization }\end{array}$ & $\begin{array}{c}0.569 \\
(0.324)\end{array}$ & $\begin{array}{c}0.551 \\
(0.304)\end{array}$ & $\begin{array}{c}0.622 \\
(0.387)\end{array}$ & $\begin{array}{c}0.590 \\
(0.348)\end{array}$ & 1.000 & $\begin{array}{c}6.138 \\
(0.887)\end{array}$ & 0.693 & 0.531 \\
\hline
\end{tabular}

Goodness-of-fit statistics for the measurement model: $\chi^{2}=230.599, d f=92, p<0.001, \chi^{2} / d f=2.507$, RMSEA $=0.069$, $\mathrm{CFI}=0.961, \mathrm{IFI}=0.961$, and TLI $=0.949^{\mathrm{a}}$, Correlations between constructs and ${ }^{\mathrm{b}}$ Squared correlations.

\subsection{Structural Equation Modeling}

Structural equation modeling (SEM) was developed to test our hypothesized relationships. The overall fit of the SEM met acceptable levels $\left(\chi^{2}=266.752, d f=94, p<0.001, \chi^{2} / d f=2.838\right.$, RMSEA $=0.076, \mathrm{CFI}=0.951, \mathrm{IFI}=0.952$, and TLI $=0.938)$. We examined the prediction power of the projected conceptual framework. Overall, the hypothesized model had a strong ability to predict loyalty for the non-profit religious organization. Specifically, about $84.1 \%$ of the total variance in volunteer travelers' loyalty was accounted for by its antecedents. As shown in Figure 2 and Table 2, the model accounted for about $65.3 \%$ of the variance in the mental well-being and about $69.9 \%$ of the variance in attitude toward the non-profit religious organization.

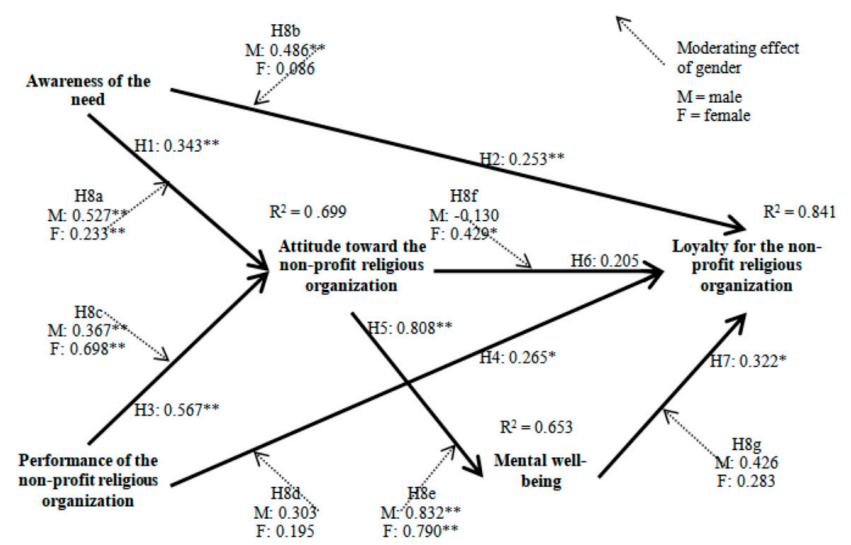

Figure 2. Structural model and baseline model evaluations $(n=320) .{ }^{*} p<0.05$ and ${ }^{* *} p<0.01$. 
Table 2. Measurement model assessment results.

\begin{tabular}{|c|c|c|c|c|}
\hline \multicolumn{3}{|c|}{ Hypothesized Associations } & \multirow{2}{*}{$\begin{array}{c}\text { Coefficients } \\
0.343\end{array}$} & \multirow{2}{*}{$\frac{t \text {-Values }}{5.466^{* *}}$} \\
\hline H1: Awareness of the need & $\rightarrow$ & $\begin{array}{l}\text { Attitude toward the non-profit } \\
\text { religious organization }\end{array}$ & & \\
\hline $\mathrm{H} 2$ : Awareness of the need & $\rightarrow$ & $\begin{array}{l}\text { Loyalty for the non-profit } \\
\text { religious organization }\end{array}$ & 0.253 & $2.666^{* *}$ \\
\hline $\begin{array}{l}\text { H3: Performance of the } \\
\text { non-profit religious organization }\end{array}$ & $\rightarrow$ & $\begin{array}{l}\text { Attitude toward the non-profit } \\
\text { religious organization }\end{array}$ & 0.567 & $8.433^{* *}$ \\
\hline $\begin{array}{l}\text { H4: Performance of the } \\
\text { non-profit religious organization }\end{array}$ & $\rightarrow$ & $\begin{array}{l}\text { Loyalty for the non-profit } \\
\text { religious organization }\end{array}$ & 0.265 & $2.246^{*}$ \\
\hline $\begin{array}{l}\text { H5: Attitude toward the } \\
\text { non-profit religious organization }\end{array}$ & $\rightarrow$ & Mental well-being & 0.808 & 9.554 * \\
\hline $\begin{array}{l}\text { H6: Attitude toward the } \\
\text { non-profit religious organization }\end{array}$ & $\rightarrow$ & $\begin{array}{l}\text { Loyalty for the non-profit } \\
\text { religious organization }\end{array}$ & 0.205 & 1.377 \\
\hline H7: Mental well-being & $\rightarrow$ & $\begin{array}{l}\text { Loyalty for the non-profit } \\
\text { religious organization }\end{array}$ & 0.322 & $2.356^{*}$ \\
\hline Variance explained: & & Total impact on loyalty: & \multicolumn{2}{|c|}{ Indirect impact on loyalty: } \\
\hline $\begin{array}{c}\mathrm{R}^{2}(\text { loyalty })=0.841 \\
\mathrm{R}^{2}(\text { mental well-being })=0.653 \\
\left.\mathrm{R}^{2} \text { (attitude }\right)=0.699\end{array}$ & & $\begin{array}{c}\beta \text { mental well-being }=0.322 * \\
\beta \text { attitude }=0.465^{* *} \\
\beta \text { performance }=0.529 * * \\
\beta \text { awareness }=0.413^{* *}\end{array}$ & \multicolumn{2}{|c|}{$\begin{array}{c}\beta \text { attitude }=0.260 * \\
\beta \text { performance }=0.264^{* *} \\
\beta \text { awareness }=0.160 * *\end{array}$} \\
\hline
\end{tabular}

The proposed effect of awareness of the need was assessed. As anticipated, awareness of the need exerted an important effect on attitude $(\beta=0.343, p<0.01)$ and loyalty $(\beta=0.253, p<0.01)$. This result supported Hypotheses 1 and 2. The hypothesized effect of performance of the non-profit religious organization was tested. Our finding indicated that performance exerted a significant impact on attitude $(\beta=0.567, p<0.01)$ and loyalty $(\beta=0.265, p<0.05)$, which supports Hypotheses 3 and 4 . Next, the influence of attitude toward the non-profit religious organization was evaluated and the outcome demonstrated that attitude exerted a critical impact over mental well-being $(\beta=0.808, p<0.01)$. Hence, Hypothesis 5 was supported. However, the effect of attitude on loyalty was not significant $(\beta=0.205$, $p>0.05)$. Thus, Hypothesis 6 was not supported. Lastly, our finding demonstrated the significant linkage between mental well-being and loyalty $(\beta=0.322, p<0.05)$, which confirmed support of Hypothesis 7.

Regarding the total effect of the research constructs, which is shown in Table 2, the performance of the non-profit religious organization contained the greatest influence on loyalty $(\beta=0.529, p<0.01)$, followed by attitude $(\beta=0.465, p<0.01)$, awareness of the need $(\beta=0.413, p<0.01)$, and mental well-being $(\beta=0.322, p<0.05)$. In regards to the mediating effect of the study variables, the performance of the non-profit religious organization $(\beta=0.264, p<0.01)$ and awareness of the need $(\beta=0.160$, $p<0.01)$ significantly affected loyalty indirectly through attitude and mental well-being. In addition, attitude included a significant indirect influence on loyalty $(\beta=0.260, p<0.05)$. This outcome suggested attitude and mental well-being played significant mediating roles within our hypothesized model.

\subsection{Baseline Model and Metric Invariance}

The hypothesized influence of gender was assessed. The respondents were split into two groups; men and women. The men's group contained 141 participants, and the women's group included 179 participants. We generated a baseline model comprised of these two gender groups. All factor loads within the baseline model were set to be identical in both groups. The results revealed that the baseline model had a satisfactory adherence to the data. Then, the model was sequentially compared with a chain of nested models by using a chi-square test. 
The Table 3 and Figure 2 exhibit the details. Our results demonstrated that the linkages between awareness of the need and loyalty $\left(\Delta \chi^{2}(1)=2.834, p>0.05\right)$, performance and loyalty $\left(\Delta \chi^{2}(1)=0.080\right.$, $p>0.05)$, attitude and mental well-being $\left(\Delta \chi^{2}(1)=0.931, p>0.05\right)$, attitude and loyalty $\left(\Delta \chi^{2}(1)=3.471\right.$, $p>0.05)$, and mental well-being and loyalty $\left(\Delta \chi^{2}(1)=0.099, p>0.05\right)$ were not significantly different between the gender sets. Therefore, Hypotheses $8 \mathrm{~b}, 8 \mathrm{~d}, 8 \mathrm{e}, 8 \mathrm{f}$, and $8 \mathrm{~g}$ were not supported. However, the results revealed that the relationship between awareness of the need and attitude $\left(\Delta \chi^{2}(1)=4.542\right.$, $p<0.05)$ and performance and attitude $\left(\Delta \chi^{2}(1)=9.128, p<0.01\right)$ were significantly different between the gender sets. Accordingly, Hypotheses $8 \mathrm{a}$ and $8 \mathrm{c}$ were supported.

Table 3. Baseline and invariance model assessment results.

\begin{tabular}{|c|c|c|c|c|c|c|}
\hline \multirow{2}{*}{ Paths } & \multicolumn{2}{|c|}{ Male Visitor $(n=141)$} & \multicolumn{2}{|c|}{ Female Visitor $(n=179)$} & \multirow{2}{*}{$\begin{array}{l}\text { Baseline Model } \\
\text { (Freely Estimated) }\end{array}$} & \multirow{2}{*}{$\begin{array}{c}\text { Nested Model } \\
\text { (Constrained to Be Equal) }\end{array}$} \\
\hline & & $t$-Values & $\beta$ & $t$-Values & & \\
\hline $\begin{array}{l}\text { Awareness of the need } \rightarrow \\
\text { Attitude toward the non-profit } \\
\text { religious organization }\end{array}$ & 0.527 & $5.106^{* *}$ & 0.233 & $3.250 * *$ & $\chi^{2}(199)=427.120$ & $x^{2}(200)=431.662^{a}$ \\
\hline $\begin{array}{l}\text { Awareness of the need } \rightarrow \\
\text { Loyalty for the non-profit } \\
\text { religious organization }\end{array}$ & 0.486 & $2.637^{* *}$ & 0.086 & 0.761 & $\chi^{2}(199)=427.120$ & $\chi^{2}(200)=429.954^{b}$ \\
\hline $\begin{array}{l}\text { Performance of the non-profit } \\
\text { religious organization } \rightarrow \\
\text { Attitude toward the non-profit } \\
\text { religious organization }\end{array}$ & 0.367 & $3.687^{* *}$ & 0.698 & $8.642 * *$ & $\chi^{2}(199)=427.120$ & $\chi^{2}(200)=436.248^{c}$ \\
\hline $\begin{array}{l}\text { Performance of the non-profit } \\
\text { religious organization } \rightarrow \\
\text { Loyalty for the non-profit } \\
\text { religious organization }\end{array}$ & 0.303 & 1.897 & 0.195 & 1.119 & $\chi^{2}(199)=427.120$ & $\chi^{2}(200)=427.200^{d}$ \\
\hline $\begin{array}{l}\text { Attitude toward the non-profit } \\
\text { religious organization } \rightarrow \\
\text { Mental well-being }\end{array}$ & 0.832 & $8.291 * *$ & 0.790 & $8.367^{* *}$ & $\chi^{2}(199)=427.120$ & $\chi^{2}(200)=428.051^{\mathrm{e}}$ \\
\hline $\begin{array}{l}\text { Attitude toward the non-profit } \\
\text { religious organization } \rightarrow \\
\text { Loyalty for the non-profit } \\
\text { religious organization }\end{array}$ & -0.130 & -0.527 & 0.429 & $2.127^{*}$ & $\chi^{2}(199)=427.120$ & $\chi^{2}(200)=430.591^{\mathrm{f}}$ \\
\hline $\begin{array}{c}\text { Mental well-being } \rightarrow \text { Loyalty } \\
\text { for the non-profit religious } \\
\text { organization }\end{array}$ & 0.426 & 1.613 & 0.283 & 1.846 & $\chi^{2}(199)=427.120$ & $\chi^{2}(200)=427.219 g$ \\
\hline Chi-square difference test & \multicolumn{4}{|c|}{ Hypotheses testing } & & \\
\hline${ }^{\mathrm{a}} \Delta \chi^{2}(1)=4.542, p<0.05$ & \multicolumn{4}{|c|}{ H8a-Supported } & & \\
\hline${ }^{\mathrm{b}} \Delta \chi^{2}(1)=2.834, p>0.05$ & \multirow{2}{*}{\multicolumn{4}{|c|}{$\begin{array}{c}\text { H8b-Not supported } \\
\text { H8c-Supported }\end{array}$}} & & \\
\hline${ }^{c} \Delta \chi^{2}(1)=9.128, p<0.01$ & & & & & & \\
\hline${ }^{\mathrm{d}} \Delta \chi^{2}(1)=0.080, p>0.05$ & \multicolumn{4}{|c|}{$\begin{array}{c}\text { H8c-Supported } \\
\text { H8d-Not supported }\end{array}$} & & \\
\hline e $\Delta \chi^{2}(1)=0.931, p>0.05$ & \multicolumn{4}{|c|}{$\begin{array}{l}\text { H8d-Not supported } \\
\text { H8e-Not supported }\end{array}$} & & \\
\hline${ }^{\mathrm{f}} \Delta \chi^{2}(1)=3.471, p>0.05$ & \multicolumn{4}{|c|}{ H8f-Not supported } & & \\
\hline g $\Delta \chi^{2}(1)=0.099, p>0.05$ & \multicolumn{4}{|c|}{ H8g-Not supported } & & \\
\hline
\end{tabular}

\section{Discussion and Implications}

This research aimed to investigate the volunteers' loyalty generation process for non-profit religious volunteer tourism organizations. The proposed theoretical framework involved the intricate associations among the awareness of the need, the performance of the organization, attitude, and the mental well-being. It comprised its influence on loyalty by considering the gender effect. The data collected through the survey methodology was utilized to assess the suggested theoretical model. Our quantitative analysis demonstrated the satisfactory power of the model for predicting volunteer travelers' loyalty. The hypothesized associations linking awareness, performance, attitude, and mental well-being were all generally supported. The moderating influence of gender in generating a positive attitude toward the volunteer tourism organization was uncovered. Overall, the purpose of the study was entirely accomplished.

The individuals' awareness of the need was an essential variable contributing to the increase of the prediction ability of the hypothesized framework. This result implies that enhancing volunteer travelers' concern for local communities' need for help is critical to induce their positive attitude 
and loyalty for the non-profit religious volunteer tourism organization. From the practical aspect, it is therefore fundamental to encourage volunteers to have high awareness/concern about various problems that the volunteer tourism destinations have, which include environmental pollution, poverty, ecological deteriorations, natural disasters, poor child education, and water shortage, through a variety of advertising campaigns for loyalty building. From the theoretical aspect, our findings generated the notion that when individuals have a strong awareness related to the problematic issues of a volunteer tourism destination, they are likely to have a better attitude toward the volunteer tourism organization and be loyal to it and its program.

Performance of the volunteer tourism organization was found to be the strongest factor among the study variables within the proposed conceptual framework. This finding implies that the performance of the organization is the main aspect of the loyalty generation process for the non-profit religious organization among the volunteer tourists. This result was coherent with the previous studies of tourism/consumer behavior, which emphasized the key role of performance in increasing the predictive ability of a theoretical model for the patrons' loyalty/purchase behavior $[7,14,15,23]$. Practically, our results highlight that for the effective elicitation of the volunteers' loyalty for the non-profit religious volunteer tourism organization, maximizing the performance of the organization and its program is fundamental. Practitioners of the organization need to make various efforts for boosting such a performance. Theoretically, our finding gives the essential information that is required to better explicate the volunteer travelers' decision/behavior, which necessarily involves the concept of performance into the framework for such a decision/behavior.

The gender moderating effect on the suggested conceptual model was empirically identified. In particular, gender exercised big influence on the magnitude of the association among the awareness of the need, the performance of the organization, and the attitude toward the organization. The relationship between the awareness of the need and the attitude was significantly stronger for men's group $(\beta=0.527$, $p<0.01)$ than that of women's $(\beta=0.233, p<0.01)$, and the relationship between performance and attitude was significantly stronger for women's group $(\beta=0.698, p<0.01)$ than that of men's $(\beta=0.367$, $p<0.01)$. This finding provided critical information, because at a similar level of the awareness of the need, male volunteer travelers showed an increase with a more positive attitude toward the volunteer tourism organization than the female travelers, and female travelers showed an increase with a more favorable attitude toward the volunteer tourism organization than male travelers at the similar level of performance perception.

The result of gender moderating effect can be explained by heroism and chivalry, which are intrinsically attributed to males $[53,60]$. Males take action when help is needed, and this action tends to enhance their self-esteem $[53,61]$. Therefore, males tend to have a stronger attitude, which is triggered by their intrinsic heroism and chivalry. Similarly, the finding that the relationship between organizational performance and attitude was significantly stronger in the women's group than the men's group, can be accounted for by female social reinforcement and affection towards their close friends [61-63]. According to Piliavin, Rodin, and Piliavin [64], females stereotypically attribute more value to the belongingness of social status. Hence, females would care more about their organizational performance than males.

Despite its importance, research on the effect of gender on the volunteer travelers' loyalty formation for the volunteer tourism organization is scant. The present research contained a theoretical value, and this study satisfactorily filled this gap. The evidence of the gender difference demonstrated in the present research provided the essential information that using gender is crucial to clearly know the volunteer travelers' attitude generation process towards non-profit religious organizations. The extant theoretical frameworks in the previous studies pertinent to volunteer travelers behaviors therefore need to be deepened with the integration of the gender effect. Our results also offered practically important information, because for the efficient enhancement of the male travelers' positive attitude toward the volunteer tourism organization, increasing their awareness of the need is important. Meanwhile, for the rapid increase of the female travelers' attitude, improving their perception regarding the performance 
of the organization is fundamental. The practitioners of the non-profit religious organization should be aware of this gender difference and its criticality when inducing volunteers' favorable attitude.

Very little was known regarding the intricate mechanisms underlying the association among awareness of the need, the performance of the non-profit religious organization, and the loyalty intention in field of volunteer tourism. In this research, we satisfactorily uncovered the mediation mechanism that comprised of attitude and mental well-being, which broadens our comprehension of the processes generating volunteer travelers' loyalty intention. The convoluted mediation mechanism offered the important theoretical information that the effect of awareness of the need and performance of the non-profit religious organization on loyalty intention can be maximized by the dynamic role of attitude toward the non-profit religious organization and mental well-being. Practically, dealing with these mediators is also significant for the efficient elicitation of volunteer travelers' loyalty intention for the non-profit religious organization.

There are few limitations, which offer future research opportunities. First, we develop this study to be adequate in volunteer tourism area, and the interpretation of our results is the most operative in the same circumstance. Hence, we recommend some cautions when applying our outcomes to different types of tourism or other consumer behavior sectors. For example, a replication of the research is needed for future research if one wishes to examine the effectiveness of our proposed conceptual model. Second, the correlation between performance and attitude is about 0.709 , which is somewhat high. In order to fully avoid the issue of multi-collinearity, the measurement design should be more carefully conducted in the future research.

\section{Conclusions}

Undoubtedly, volunteer travelers' decisions and behaviors pertinent to the volunteer tourism program/organization is one of the crucial issues in the entire tourism industry. However, the volunteer travelers' loyalty generation process especially for the non-profit religious organization and the triggers of such processes have not been fully explored. This research filled this gap. The role of the awareness of the need, the performance of the organization, the attitude toward the organization, and the mental well-being was unearthed in a clear manner and our proposed conceptual model satisfactorily provided relevant evidence. In addition, we clearly explored the gender moderating role. The results of our research can help volunteer tourism practitioners from non-profit religious organizations invent useful tactics to retain existing volunteers and to improve their loyalty by using the variables of this study as tools. The theoretical base related to individuals' decision formation and loyalty in religious volunteer tourism is still in its infancy. Hence, our study contains highly valuable material and originality. The present research could assist subsequent studies about volunteer tourism through non-profit religious organizations.

Author Contributions: Methodology, H.H.; formal analysis, H.H.; writing—original draft preparation, H.H. and S.L.; writing-review and editing, S.L. and A.A.-M.; visualization, S.L.; project administration, H.H., P.T.-V. and A.A.-M.; funding acquisition, P.T.-V. All authors have read and agreed to the published version of the manuscript.

Funding: This research received no external funding.

Conflicts of Interest: The authors declare no conflict of interest. 


\section{Appendix A}

Awareness of the need

- Through the volunteer tourism program of the Good News Corps: I have become aware that people need help.

- I have increased my awareness of helping others by participating in the volunteer tourism program of the Good News Corps.

- My behavior in the volunteer tourism program of the Good News Corps can help people and communities.

- My actions in the volunteer tourism program of the Good News Corps can affect the lives of other people.

Performance of the non-profit religious organization

- The Good News Corps has worked satisfactorily.

- The information given by the Good News Corps has been appropriate.

- $\quad$ The Good News Corps has fulfilled all its promises.

Attitude toward the non-profit religious organization

- I like volunteering through the Good News Corps very much

- My evaluation of the Good News Corps' voluntary activities is positive.

- I feel that volunteering through the Good News Corps is an excellent experience.

- I like the voluntary activities of the Good News Corps.

Mental well-being

- In most aspects, my life has become close to ideal after participating in the VT program of the Good News Corps.

- The conditions of my life have become excellent after participating in the VT program of the Good News Corps.

- In general, I consider myself very happy after participating in the VT program of the Good News Corps.

Loyalty for the non-profit religious organization

- I am passionate about volunteer activities through the VT program of the Good News Corps.

- When someone criticizes the VT program of the Good News Corps, I feel like I have to defend it.

\section{References}

1. Han, H.; Meng, B.; Chua, B.; Ryu, H.; Kim, W. International volunteer tourism and youth travelers-An emerging tourism trend. J. Travel Tour. Mark. 2019, 36, 46-62. [CrossRef]

2. Wearing, S. Volunteer Tourism; Experiences that Makes a Difference; Cabi Publishing: New York, NY, USA, 2001.

3. Wearing, S.; McGehee, N.G. Volunteer tourism: A review. Tour. Manag. 2013, 38, 120-130. [CrossRef]

4. Ellis, C. When volunteers pay to take a trip with scientists-participatory environmental research tourism (PERT). Hum. Dimens. Wildl. 2003, 8, 75-80. [CrossRef]

5. Meng, B.; Ryu, H.; Chua, B.; Han, H. Predictors of intention for continuing volunteer tourism activities among young tourists. Asia Pac. J. Tour. Res. 2020, 25, 261-273. [CrossRef]

6. Pompurová, K.; Marčeková, R.; Šebová, L'.; Sokolová, J.; Žofaj, M. Volunteer tourism as a sustainable form of tourism-The case of organized events. Sustainability 2018, 10, 1468. [CrossRef]

7. Brown, S. Travelling with a purpose: Understanding the motives and benefits of volunteer vacationers. Curr. Issues Tour. 2005, 8, 479-496. [CrossRef]

8. Pan, T.J. Personal transformation through volunteer tourism: The evidence of Asian students. J. Hosp. Tour. Manag. 2017, 41, 609-634. [CrossRef]

9. Chua, B.; Lee, S.; Kim, H.; Han, H. Investigation of cruise vacationers' behavioral intention formation in the fast-growing cruise industry: The moderating impact of gender and age. J. Vacat. Mark. 2019, 25, 51-70. [CrossRef] 
10. Ghaderi, Z.; Hatamifar, P.; Ghahramani, L. How smartphones enhance local tourism experiences? Asia Pac. J. Tour. Res. 2019, 24, 778-788. [CrossRef]

11. Hwang, J.; Lee, J. A strategy for enhancing senior tourists' well-being perception: Focusing on the experience economy. J. Travel Tour. Mark. 2019, 36, 314-329. [CrossRef]

12. Hwang, J.; Choi, J.K. An investigation of passengers' psychological benefits from green brands in an environmentally friendly airline context: The moderating role of gender. Sustainability 2018, 10, 80. [CrossRef]

13. Lind, H.B.; Nordfjærn, T.; Jørgensen, S.H.; Rundmo, T. The value-belief-norm theory, personal norms and sustainable travel model choice in urban areas. J. Environ. Psychol. 2015, 44, 119-125. [CrossRef]

14. Oliver, R.L. Satisfaction: A Behavioral Perspective on the Consumer, 2nd ed.; McGraw-Hill: New York, NY, USA, 2010.

15. Taylor, S.A.; Baker, T.L. An assessment of the relationship between service quality and customer satisfaction in the formation of consumers' purchase intentions. J. Retail. 1994, 70, 163-178. [CrossRef]

16. Hwang, J.; Kim, H. Consequences of a green image of drone food delivery services: The moderating role of gender and age. Bus. Strateg. Environ. 2019, 28, 872-884. [CrossRef]

17. Meng, B.; Han, H. Investigating individuals' decision formation for working-holiday tourism: Role of sensation-seeking and gender. J. Travel Tour. Mark. 2018, 35, 973-987. [CrossRef]

18. Rogers, M. Volunteerism is on the rise: Purpose-driven travelers seek meaningful journeys. TravelAgent 2007, 331, 20-24.

19. Wearing, S. Examining best practice in volunteer tourism. In Volunteering as Leisure/Leisure as Volunteering: An International Assessment; Robert, A., Stebbins, M., Eds.; Cabi Publishing: New York, NY, USA, 2004; pp. 209-224.

20. McGehee, N.; Santos, C. Social change, discourse and volunteer tourism. Ann. Tour. Res. 2005, 32, 760-779. [CrossRef]

21. Campbell, L.; Smith, C. What makes them pay? Values of volunteer tourists working for sea turtle conservation. Environ. Manag. 2006, 38, 84-98. [CrossRef]

22. Kennedy, K.; Dornan, D. An overview: Tourism non-governmental organizations and poverty reduction in developing countries. Asia Pac. J. Tour. Res. 2009, 14, 183-200. [CrossRef]

23. Bussell, H.; Forbes, D. Understanding the volunteer market: The what, where, who and why of volunteering. Int. J. Nonprofit Volunt. Sect. Mark. 2002, 7, 244-257. [CrossRef]

24. Broad, S. Living the Thai life e a case study of volunteer tourism at the Gibbon Rehabilitation Project. Tour. Recreat. Res. 2003, 28, 63-72. [CrossRef]

25. Cnaan, R.; Goldberg-Glen, R. Measuring motivation to volunteer in human services. J. Appl. Behav. Sci. 1991, 27, 269-284. [CrossRef]

26. Ryan, R.; Kaplan, R.; Grese, R. Predicting volunteer commitment in environmental stewardship programs. J. Environ. Plann. Man. 2001, 44,629-648. [CrossRef]

27. Lo, A.; Lee, C. Motivations and perceived value of volunteer tourists from Hong Kong. Tour. Manag. 2011, 32, 326-334. [CrossRef]

28. Stoddart, H.; Rogerson, C. Volunteer tourism: The case of habitat for humanity South Africa. GeoJournal 2004, 60, 311-318. [CrossRef]

29. Schwartz, S.H. Normative influences on altruism. In Advances in Experimental Social Psychology; Berkowitz, L., Ed.; Academic Press: New York, NY, USA, 1977; Volume 10, pp. 221-279.

30. Steg, L.; De Groot, J. Explaining prosocial intentions: Testing causal relationships in the norm activation model. Br. J. Soc. Psychol. 2010, 49, 725-743. [CrossRef]

31. Campbell, K. You Name It. Volunteers Do It. Christ Sci Monitor. 1999, 91, 19.

32. Newton, J.; Tsarenko, Y.; Ferraro, C.; Sands, S. Environmental concern and environmental purchase intentions: The mediating role of learning strategy. J. Bus. Res. 2015, 68, 1974-1981. [CrossRef]

33. Paco, A.; Rapose, M. Green segmentation: An application to the Portuguese consumer market. Mark. Intell. Plan. 2009, 27, 364-379. [CrossRef]

34. Kwon, W.; Englis, B.; Mann, M. Are third-party green-brown ratings believed? The role of prior brand loyalty and environmental concern. J. Bus. Res. 2016, 69, 815-822. [CrossRef]

35. Verma, V.K.; Chandra, B.; Kumar, S. Values and ascribed responsibility to predict consumers' attitude and concern towards green hotel visit intention. J. Bus. Res. 2019, 96, 206-216. [CrossRef] 
36. Stern, P.C. Toward a coherent theory of environmentally significant behavior. J. Soc. Issues 2000, 56, 407-424. [CrossRef]

37. Al-Ansi, A.; Han, H. Role of halal-friendly destination performances, value, satisfaction, and trust in generating destination image and loyalty. J. Destin. Mark. Manag. 2019, 13, 51-60. [CrossRef]

38. Song, H.J.; Lee, C.K.; Kim, M.J.; Bendle, L.J.; Shin, C.Y. Investigating relationships among festival quality, satisfaction, trust, and support: The case of an oriental medicine festival. J. Travel Tour. Mark. 2014, 31, 211-228. [CrossRef]

39. Kang, S.K.; Lee, C.K.; Lee, Y.K.; Li, D.X. A quality-value-attitude model: The case of EXPO 2010 Shanghai. J. Hosp. Tour. Res. 2016, 40,764-771. [CrossRef]

40. Ajzen, I. The theory of planned behavior. Organ. Behav. Hum. Dec. 1991, 50, 179-211. [CrossRef]

41. Yen, Y.S. Route factors influencing trust and attitude toward TV shopping. Serv. Ind. J. 2017, 38, 1-29. [CrossRef]

42. Moon, H.; Yoon, H.J.; Han, H. Role of airport physical environment in the satisfaction generation process: Mediating the impact of traveler emotion. Asia Pac. J. Tour. Res. 2016, 21, 193-211. [CrossRef]

43. Rodríguez-Arauz, G.; Ramírez-Esparza, N.; Smith-Castro, V. Food attitudes and well-being: The role of culture. Appetite 2016, 105, 180-188. [CrossRef]

44. Stark, J.; Singleton, P.A.; Uhlmann, T. Exploring children's school travel, psychological well-being, and travel-related attitudes: Evidence from primary and secondary school children in Vienna, Austria. Travel Behav. Soc. 2019, 16, 118-130. [CrossRef]

45. Kim, H.; Chua, B.; Lee, S.; Boo, H.; Han, H. Understanding airline travelers' perceptions of well-being: The role of cognition, emotion, and sensory experiences in airline lounges. J. Travel Tour. Mark. 2016, 33, 1213-1234. [CrossRef]

46. Hwang, J.; Hyun, S. The antecedents and consequences of brand prestige in luxury restaurants. Asia Pac. J. Tour. Res. 2012, 17, 656-683. [CrossRef]

47. Anderson, L.; Ostrom, A.; Corus, C.; Fisk, R.; Gallan, A.; Giraldo, M.; Mende, M.; Mulder, M.; Rayburn, S.; Rosenbaum, M.; et al. Transformative service research: An agenda for the future. J. Bus. Res. 2013, 66, 1203-1210. [CrossRef]

48. Troebs, C.; Wagner, T.; Heidemann, F. Transformative retail services: Elevating loyalty through customer well-being. J. Retail. Consm. Serv. 2018, 45, 198-206. [CrossRef]

49. González Hernández, J.; Muñoz-Villena, A.J.; Gómez-López, M. Stress Regulation, Physical Activity, and Perseverance in Spanish Teenagers with Perfectionist Trends. Sustainability 2018, 10, 1489. [CrossRef]

50. Nadinloyi, K.; Sadeghi, H.; Hajloo, N. Relationship between job satisfaction and employee mental health. Procedia-Soc. Behav. Sci. 2013, 84, 293-297. [CrossRef]

51. Archer, J. Sex differences in social behavior: Are social role and evolutionary explanations compatible? Am. Psychol. 1996, 51, 909-917. [CrossRef]

52. Buss, D. The evolutionary psychology of human social strategies. In Social Psychology: Handbook of Basic Principles; Higgins, E., Kruglanski, A., Eds.; Guilford Press: New York, NY, USA, 1996; pp. 3-38.

53. Eagly, A.; Crowley, M. Gender and helping behavior: A meta-analytic review of the social psychological literature. Psychol. Bull. 1986, 100, 283. [CrossRef]

54. Alexander, Z. The impact of a volunteer tourism experience, in South Africa, on the tourist: The influence of age, gender, project type and length of stay. Tour. Manag. Perspect. 2012, 4, 119-126. [CrossRef]

55. Han, H.; Meng, B.; Kim, W. Bike-traveling as a growing phenomenon: Role of attributes, value, satisfaction, desire, and gender in developing loyalty. Tour. Manag. 2017, 59, 91-103. [CrossRef]

56. Hwang, J.; Lee, J.S.; Kim, H. Perceived innovativeness of drone food delivery services and its impacts on attitude and behavioral intentions: The moderating role of gender and age. Int. J. Hosp. Manag. 2019, 81, 94-103. [CrossRef]

57. Cheng, Y.; Lv, Y.; Rosenberg, M.; Hou, L. Decision Making of Non-Agricultural Work by Rural Residents in Weifang, China. Sustainability 2018, 10, 1647. [CrossRef]

58. Wang, C.; Qu, H.; Hsu, M. Toward an integrated model of tourist expectation formation and gender difference. Tour. Manag. 2016, 54, 58-71. [CrossRef]

59. Hair, J.F.; Black, W.C.; Babin, B.J.; Anderson, R.E. Multivariate Data Analysis, 7th ed.; Prentice-Hall: Upper Saddle River, NJ, USA, 2010; pp. 600-638. 
60. Broverman, I.K.; Vogel, S.R.; Broverman, D.M.; Clarkson, F.E.; Rosenkrantz, P.S. Sex-Role Stereotypes: A Current Appraisal 1. J. Soc. Issues 1972, 28, 59-78. [CrossRef]

61. Kiani, I.; Laroche, M.; Paulin, M. Development of market Mavenism traits: Antecedents and moderating effects of culture, gender, and personal beliefs. J. Bus. Res. 2016, 6, 1120-1129. [CrossRef]

62. Belle, D. Lives in stress. In Women and Depression; Sage Publication Inc.: Beverly Hills, CA, USA, 1982; Volume 45.

63. Bernard, J. The Female World; Simon \& Schuster: New York, NY, USA, 1981.

64. Piliavin, I.; Rodin, J.; Piliavin, J. Good Samaritanism: An underground phenomenon? J. Pers. Soc. Psychol. 1969, 13, 289. [CrossRef]

(C) 2020 by the authors. Licensee MDPI, Basel, Switzerland. This article is an open access article distributed under the terms and conditions of the Creative Commons Attribution (CC BY) license (http://creativecommons.org/licenses/by/4.0/). 